\title{
Determination of antibacterial activity of tea water concentrates against $E$. coli and S. aureus
}

\section{Rohan Ali ${ }^{1}$, Navid Iqbal ${ }^{2}$, Kiran Mukhtiar ${ }^{3}$, Saqlain Jehan ${ }^{2}$, Ali Abbas ${ }^{1}$, Muhmmad Lateef ${ }^{4}$, Abdur Raziq ${ }^{5}$, Muhammad Waseem Khan ${ }^{6}$ and Hayat Ullah $^{5^{*}}$}

1. Department of Microbiology, Government College University Faisalabad, Punjab-Pakistan

2. Institute of Biotechnology and Genetic Engineering, The University of Agriculture Peshawar-Pakistan

3. Department of Environmental Sciences, Faculty of Biological Sciences, Quaid-i-Azam University, Islamabad-

Pakistan

4. Biotechnology Department of Centre for Agricultural Biochemistry \& Biotechnology Faculty of Agriculture, University of Agriculture-Faisalabad

5. Department of Bioinformatics \& Biotechnology, Faculty of Life Science, Government College University Faisalabad-Pakistan

6. Department of Biotechnology, Faculty of Life Sciences and Informatics, Balochistan University of Information Technology Engineering and Management Sciences, Quetta-Pakistan

*Corresponding author's email: hayatullah22@gcuf.edu.pk

Citation

Rohan Ali, Navid Iqbal, Kiran Mukhtiar, Saqlain Jehan, Ali Abbas, Muhmmad Lateef, Abdur Raziq, Muhammad Waseem Khan and Hayat Ullah. Determination of antibacterial activity of tea water concentrates against E. coli and S. aureus. Pure and Applied Biology. Vol. 10, Issue 4, pp962-968. http://dx.doi.org/10.19045/bspab.2021.100100

\begin{tabular}{llll}
\hline \hline Received: 17/10/2020 & Revised: 18/12/2020 & Accepted: 28/12/2020 & Online First: 02/01/2021 \\
\hline \hline
\end{tabular}

\section{Abstract}

Tea is one of the most common beverages consumed since centuries. It has antimicrobial activity against various pathogens. Current research study was designed to evaluate and compare the antibacterial activity of different commercially available tea (green and black) concentrates against pathogenic bacterial strains of gram-negative Escherichia coli (E. coli) and gram-positive Staphylococcus aureus (S. aureus). Modified broth micro dilution method was used for the evaluation and analysis of tea samples. For this purpose, stock solutions of green and black tea concentrates, mannitol broth and bacterial suspensions were prepared. $E$. coli and $S$. aureus $10 \mu \mathrm{l}$ suspension was added according to labelled wells and incubated. Minimum inhibitory concentration was confirmed by well diffusion method. The results suggest that green tea water concentrate is effective against both strains of these pathogenic bacteria, inhibiting their growth at 6.2 $\mathrm{mg} / \mathrm{ml}$. The black tea water concentrate is found more efficient against E. coli than $S$. aureus, with the minimum inhibitory concentration at $6.2 \mathrm{mg} / \mathrm{ml}$ and $12.5 \mathrm{mg} / \mathrm{ml}$ respectively. The findings of the current study encourage and recommend the use of both green and black tea in normal routines as well as a traditional medicinal remedy for the treatment of various human ailments.

Keywords: Antibacterial activity; Growth inhibition; Micro dilution; Modified broth; Tea (Camellia sinensis)

\section{Introduction}

In beverages, tea (Camellia sinensis) is most commonly consumed in the world. Tea contains ingredients that refresh mind by stimulating and producing good feelings [1]. Tea has various types and flavours such as oolong tea, green tea and black tea. Green tea is most commonly used due to its antioxidant 
and antimicrobial activities. In the modern world, green tea flavour is used in various items such as candies, soft drinks and ice creams [2]. Tea is well known as a therapeutic agent for different maladies [3, 4]. According to research studies, tea have antimicrobial, anti-inflammatory, antioxidant, anti-cancer and antibacterial activities against number of pathogens $[5,6]$. In ancient India and China, human ailments were cured with tea as natural remedy [7].

Green tea is product of C. sinensis dried leaves, however black tea require fermentation process that produce thearubigins and theaflavins. These oligomeric polyphenolic compounds derived from flavanol tea units are biologically active components of tea [8]. Main flavonoids found in tea are tannins, catechins and theaflavins. Catechin is subdivided into epigallocatechin gallate (EGCG), epicatechin (EC), epigallocatechin (EGC) and epicatechin gallate (ECG) [9]. Polyphenols quantity in black and green tea is about $10 \%$ and $40 \%$ respectively [10]. Green tea has antimicrobial activity against gram-positive and gram-negative bacteria [11]. EGCG have maximum radical scavenging activity and is the most abundant polyphenol, due to popularity of tea and absence to toxicity.

Tea and caffeine might contribute to and promote anticarcinogenic effects [12, 13]. Animal models and cell line studies have shown antiangiogenic, anticarcinogenic and antiproliferative effects of tea flavonoids [12, 13]. According to literature, in presence of tea, various pathogens (Aeromonas sobria, Clostridium perfringens, Bacillus cereus, Staphylococcus aureus (S. aureus), Pleisomonas shigelloides and Vibrio parahaemolyticus), fail to grow $[13,14]$. The objective of current research study was based on determination of antimicrobial activity of green tea and black tea against gram-positive bacteria (Staphylococcus aureus) and gramnegative bacteria (Escherichia coli).

\section{Materials and Methods}

Tea concentrates preparation

Tea samples $(20 \mathrm{~g})$ were collected in flasks $(250 \mathrm{ml})$, distilled water $(150 \mathrm{ml})$ was added and kept on shaking incubator (ES-20) at $\left(26-30^{\circ} \mathrm{C}\right)$ for three days. After incubation, the samples solution was filtered with the help of Whatman filter paper. The filtrates were separated in two different screw capped flasks. For solvent evaporation Rotavapor Buchi Rotavapor (R-200) equipment was used.

\section{Mannitol broth preparation}

Mannitol broth $(50 \mathrm{ml})$ was prepared in $(250$ ml) flask and screw capped tubes. The broth was poured and stored at $5{ }^{\circ} \mathrm{C}$. The test microorganisms (E. coli and S. aureus) were inoculated at $10^{6}$ colony forming units into tubes and vortexed gently.

\section{Determination of minimum inhibitory concentration (MIC)}

Green tea and black tea stock solutions were prepared for each sample by adding $200 \mathrm{mg}$ concentrate in $1 \mathrm{ml}$ distilled water (200 $\mathrm{mg} / \mathrm{m} 1)$. To remove debris, the stock was centrifuged at $1000 \mathrm{rpm}$. Sterile micro-titer plate was used for determination of MIC. The plate first 4 rows were labelled, $1^{\text {st }}$ row: s-g-w-1 to s-g-w-8, $2^{\text {nd }}$ row: egw1 to e-g-w$8,3^{\text {rd }}$ row: s-b-w- 1 to s-b-w- 8 and $4^{\text {th }}$ row: eb-w-1 to e-b-w-8 respectively. Mannitol broth $40 \mu$ was added through micropipette in to each well respectively. $50 \mu 1$ mannitol broth was added to positive-control to $9^{\text {th }}$ and $10^{\text {th }}$ well and negative-control to $9^{\text {th }}$ and $10^{\text {th }}$ wells of microtiter plate (96U-MS-9096UZ) respectively.

For green tea, stock solution $40 \mu \mathrm{l}$ was added to $1^{\text {st }}$ row, well (s-g-w-1), the concentrates were properly dispensed than $40 \mu$ solution was transferred to well (s-g-w-2). The process was repeated up to $8^{\text {th }}$ well (s-g-w-8) respectively. Finally, $40 \mu \mathrm{l}$ solution was discarded. Similar practice was repeated to 
$8^{\text {th }}$ (s-g-w-8) well respectively and $40 \mathrm{ml}$ solution was discarded from $8^{\text {th }}(\mathrm{s}-\mathrm{g}-\mathrm{w}-8)$ well. Similar steps was done for $2^{\text {nd }}$ row (eg-w-1 to e-g-w-8) wells. For dilutions of black tea, similar practice was done to $3^{\text {rd }}$ row (s-b-w-1 to $s-b-w-8)$ wells of plate and $4^{\text {th }}$ row (e-b-w-1 to e-b-w-8). The concentrates of tea (green and black) were $(0.78,1.56,3.12,6.25,12.5,25,50$, and 100 $\mathrm{mg} / \mathrm{ml}$ ) respectively.

Suspension of Staphylococcus aureus ( $S$. aureus) $10 \mu \mathrm{l}$ through micropipette was added to $1^{\text {st }}$ and $3^{\text {rd }}$ row of plate. $10 \mu \mathrm{l}$ suspension of E.coli was added to $2^{\text {nd }}$ and $4^{\text {th }}$ row of microtiter plate and kept on incubation for one day at temperature (35 $\left.{ }^{\circ} \mathrm{C}\right)$. Methyl red dye $15 \mu \mathrm{l}$ solution was added to every well of microtiter plate respectively. With the help of plate-reader at $(450 \mathrm{~nm})$, optical density of wells was noted.

\section{MIC (minimum inhibitory concentration)}

Each concentrate stock solution (100 $\mathrm{mg} / \mathrm{ml}$ ) was prepared by adding $100 \mathrm{mg}$ in $1 \mathrm{ml}$ distilled water and centrifuged at 2000 rpm. Test microorganisms ( $S$. aureus and E. coli), suspensions $\left(10^{6}\right.$ colony forming units) were inoculated on warmed mueller-hinton agar plates. Uniform size of wells was made on agar plates and $(50 \mu \mathrm{l})$ tea concentrates was added to each well respectively and incubated at $37^{\circ} \mathrm{C}$ for 24 hours.

\section{Results}

\section{Green tea water concentrates antibacterial activity}

The minimum inhibitory concentration value of green tea concentrate for both the test organism was found at the concentration of $6.2 \mathrm{mg} / \mathrm{ml}$. The growth of test microorganism was inhibited at 100, 50, 25, 12.5 and $6.25 \mathrm{mg} / \mathrm{m} 1$. Lower inhibition was found at $6.2 \mathrm{mg} / \mathrm{m} 1$ (Fig. 1). Well diffusion method and confirmatory test resulted that both test microorganisms are susceptible to green tea concentrations up to $10 \mathrm{mg} / \mathrm{ml}$ and resistant at $1 \mathrm{mg} / \mathrm{ml}$ (Table 1). $S$. aureus is susceptible up to $10 \mathrm{mg} / \mathrm{ml}$ concentrates of green tea with MIC $6.2 \mathrm{mg} / \mathrm{ml}$, slightly resistant to concentrates of black tea with MIC $12.5 \mathrm{mg} / \mathrm{ml}$.

\section{Black tea concentrates antibacterial activity}

By modified broth micro-dilution method, the MIC value of black tea concentrate was found at 12.5 and $6.25 \mathrm{mg} / \mathrm{ml}$, for $S$. aureus and E. coli, respectively. Growth of $S$. aureus concentrates at $12.5 \mathrm{mg} / \mathrm{ml}$ at dilutions of $100,50,25$ was inhibited whereas the growth of $E$. coli was inhibited at $6.25 \mathrm{mg} / \mathrm{ml}$. At concentration of 100 $\mathrm{mg} / \mathrm{ml}$, maximum inhibition was observed and at concentrations of 6.25 and 12.5 $\mathrm{mg} / \mathrm{ml}$, E. coli and S. aureus was resistant respectively (Fig. 2). Well diffusion method indicated that $S$. aureus have shown resistance at $10.0 \mathrm{mg} / \mathrm{ml}$ concentration and E. coli have shown resistant at $1.0 \mathrm{mg} / \mathrm{ml}$ concentration as shown in (Table 1). The results show that $E$. coli is more susceptible to black and green tea concentrates having MIC $6.25 \mathrm{mg} / \mathrm{ml}$.

\section{Discussion}

This research study conducted for antimicrobial activity of black tea and green tea at different concentrates resulted effects against pathogenic bacteria (Staphylococcus aureus (S. aureus) and Escherichia coli (E. coli)). Green tea concentrates resulted better antibacterial activity against $E$. coli and $S$. aureus that was confirmed by well diffusion method as indicated in (Fig. 1, 2 \& Table 1). The effects of black tea concentrates as antibacterial agent is comparatively less pronounced than green tea [15]. The basic explanation behind this difference in antibacterial activity is due to presence of various bio-active secondary metabolite components [16]. The present analysis demonstrates that consumption of green tea and black tea is healthy in constrained 
amount as it has potential to inhibit the growth of various pathogenic microorganisms.

According to literature, herbal plants tested for antimicrobial activity is widely accessible. Previous research studies have also reported that black tea and green tea solvents have potential of antioxidant properties and antimicrobial activity [16]. Black tea and green tea have strong antimicrobial activity against various pathogens i.e. E. coli and S. aureus. Tea (black and green) can also be used as alternate of antibiotics against bacterial infections [15]. Tea extracts are used as antiadhesive agent to stop pathogenic bacteria adhesion to host cell membrane $[17,18]$. It is confirmed that tea has been proven safe, less costly, and easily available compound [19].

Camellia sinensis leaves contain polyphenols such as alkaloids, tannins, catechin and different polyphenols that contain catechin as critical antibacterial compound [17]. Catechin pulverizes cell layer and decrease bacterial cell growth and development. Catechin is simplest compound, categorized in various components such as Epicatechin (EC), Epicatechin gallate (ECG),
Epigallocatechin (EGC) and Epigallocatechin gallate (EGCG) that have strong anti-oxidant properties [20, 21]. Green tea and black tea polyphenols play important role by increase of hepatic AMPK (5'adenosylmonophosphate activated protein kinase) and induce weight loss to treat obesity [22]. It is suggested that green tea polyphenols increase production of AMPK with help of intestinal SCFA (short chain fatty-acids) production [23]. Another study reveals that green tea, black tea and oolong tea contain $\alpha$-glucosidase inhibitors that have inhibitory potential to tea phenols that makes tea phenols capable to control postprandial hyperglycaemia [24].

Furthermore, green and black tea contains caffeine that has the capability to stop cell division and spore germination [25]. ECG and EGCG, break bacterial cell lipid bilayer by adhering on proteins that destroy morphology and biofilm relatively. Polyphenols (caffeine) is found in huge amount in black tea in oxidized form [19-26]. Therefore, green tea concentrates have potential antibacterial activity as compared with black tea concentrates [27]

Table 1. Effectiveness of tea (black and green) concentrations against gram-negative bacteria $(E$. coli) and gram-positive bacteria ( $S$. aureus)

\begin{tabular}{|c|c|c|c|c|c|c|}
\hline \multirow{2}{*}{ Microorganism } & \multicolumn{5}{|c|}{ Inhibition activity } \\
\cline { 2 - 7 } & \multicolumn{3}{|c|}{ Black tea concentrates } & \multicolumn{3}{c|}{ Green tea concentrates } \\
\hline Tea concentrates $(\mathbf{m g} / \mathbf{m l})$ & 100.0 & 10.0 & 1.0 & 100.0 & 10.0 & 1.0 \\
\hline S. aureus & $\mathrm{S}$ & $\mathrm{R}$ & $\mathrm{R}$ & $\mathrm{S}$ & $\mathrm{S}$ & $\mathrm{R}$ \\
\hline E. coli & $\mathrm{S}$ & $\mathrm{S}$ & $\mathrm{R}$ & $\mathrm{S}$ & $\mathrm{S}$ & $\mathrm{R}$ \\
\hline
\end{tabular}

$\mathrm{R}=$ Resistant, $\mathrm{S}=$ Susceptible 


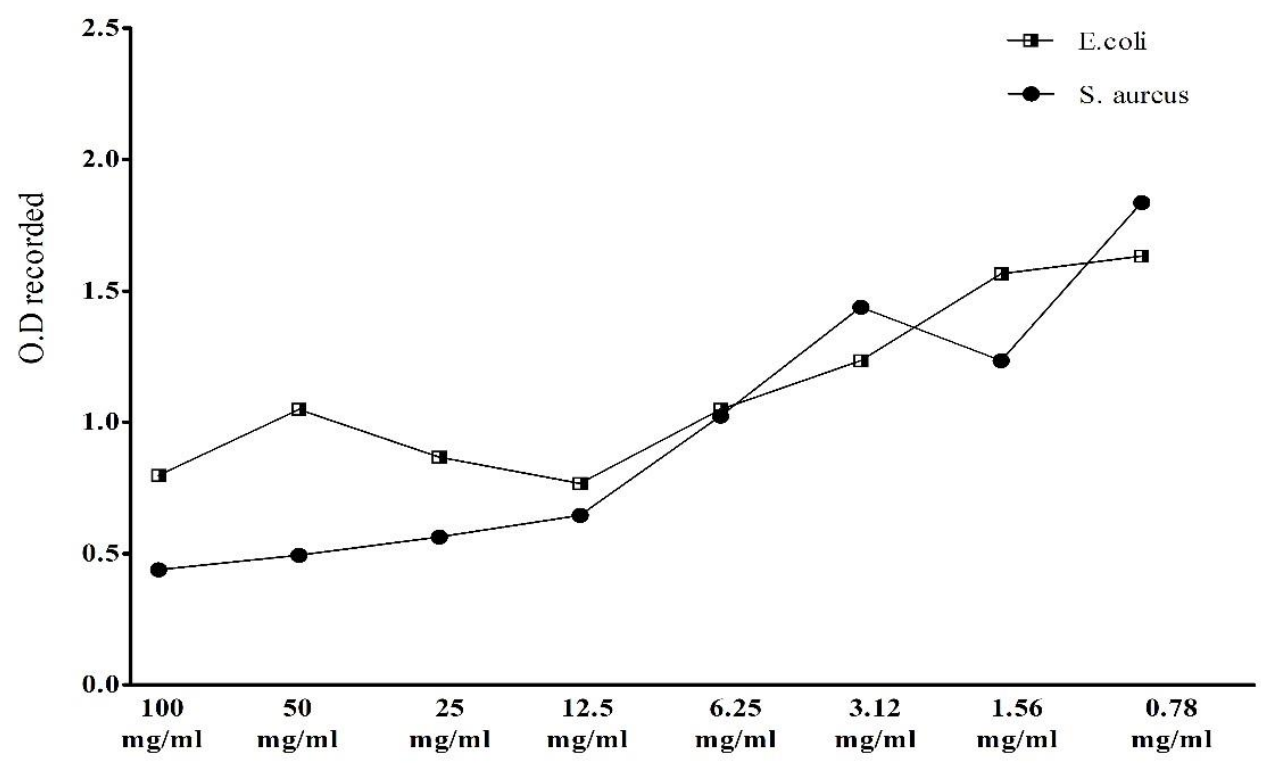

Figure 1. Green tea concentrates, antibacterial activity against gram-negative bacteria (E. coli) and gram-positive bacteria (S. aureus)

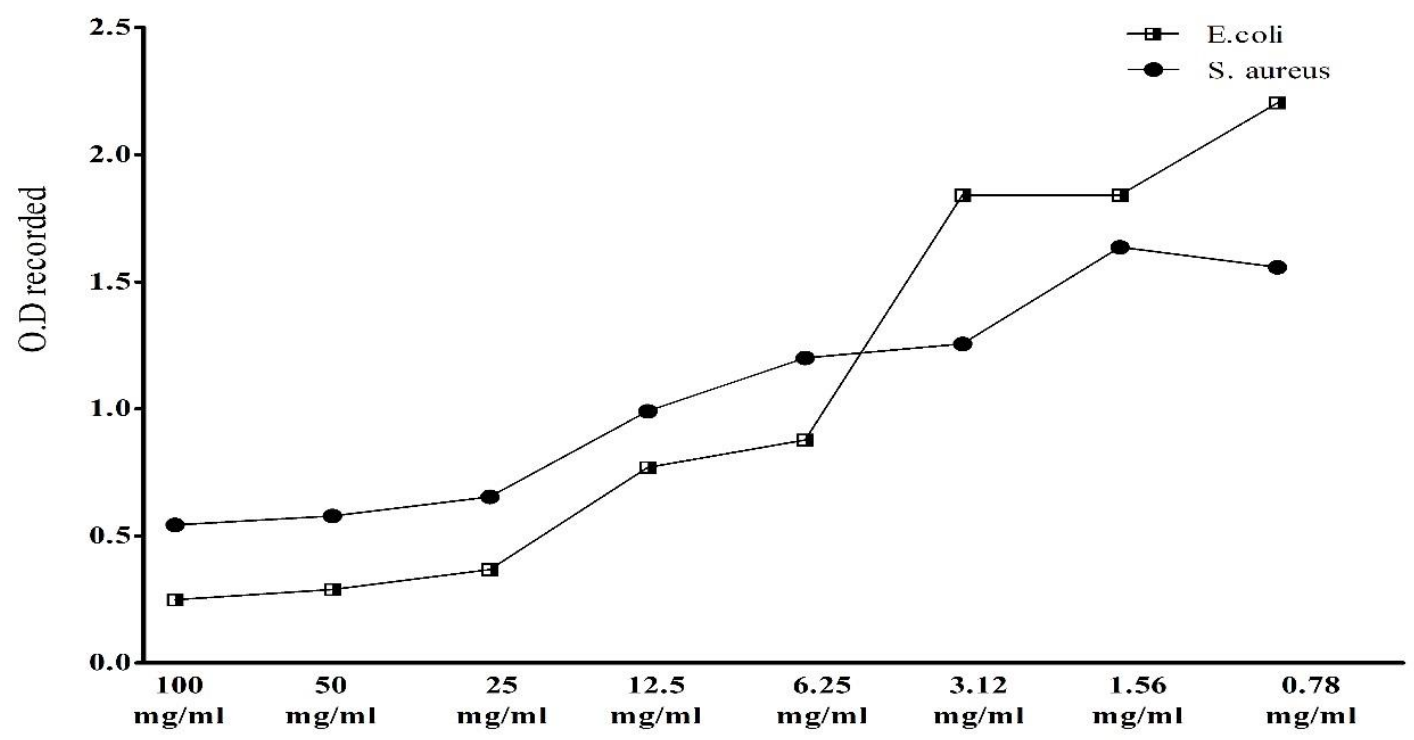

Figure 2. Black tea concentrates, antibacterial activity against gram-negative bacteria (E. coli) and gram-positive bacteria (S. aureus)

\section{Conclusion}

According to current research study, green tea has potential to inhibit growth of $E$. coli and $S$. aureus. However, E. col $i$ is relatively more susceptible to black tea than green tea concentrations. S. aureus indicates slight resistance to concentrates of black tea. Therefore, current research study supports the recommended use of tea (black and green tea) in folk medicines and beverages in satisfactory quantity.

Authors' contributions 
Conceived and designed the experiments: A Ali, A Rohan, I Navid, WK Muhammad Performed the experiments: M Kiran, J Saqlain, R Abdur, Analyzed the data: U Hayat, Contributed materials/ analysis/ tools: A Ali, L Muhammad Wrote the paper: U Hayat.

\section{Acknowledgment}

Authors would like to thank Lab technicians, for his assistance and technical support.

\section{References}

1. Shrivastava RR, Pateriya P \& Singh M (2018). Green tea-A short review. Int J Ind Herbs Drugs 3(2): 12-21.

2. Khan N \& Mukhtar H (2013). Tea and health: studies in humans. Curr Pharm Design 19(34): 6141-6147.

3. Tiwari R, Latheef SK, Ahmed I, Iqbal H, Bule MH, Dhama K, Samad HA, Karthik $\mathrm{K}$, Alagawany M, El-Hack ME \& Yatoo MI (2018). Herbal immunomodulators-a remedial panacea for designing and developing effective drugs and medicines: current scenario and future prospects. Curr Drug Metab 19(3): 264301.

4. Yousafzai A, Saleem S, Jahan N, Javed F, Khan MW \& Kanwal R (2012). Extraction of active components of Aloe Vera to treat Acne/Pimple. J Appl Emer Sci 3(1): 65-71.

5. Koech KR, Wachira FN, Ngure RM, Wanyoko JK, Bii CC, Karori SM \& Kerio LC (2014). Antioxidant, antimicrobial and synergistic activities of tea polyphenols. Afr Crop Sci J 22: 837-846.

6. Manea AM, Vasile BS, Meghea A (2014). Antioxidant and antimicrobial activities of green tea extract loaded into nanostructured lipid carriers. CR Chim 17(4):331-341.

7. Namita P, Mukesh R \& Vijay KJ (2012). Camellia sinensis (green tea): a review. Global J Pharmacol 6(2): 52-59.
8. Henning SM, Niu Y, Lee NH, Thames GD, Minutti RR, Wang H, Go VLD \& Heber D (2004). Bioavailability and antioxidant activity of tea flavanols after consumption of green tea, black tea, or a green tea extract supplement. Am J Clin Nutr 80: 1558-1564.

9. McKay DL \& Blumberg JB (2007). Roles for epigallocatechin gallate in cardiovascular disease and obesity: an introduction. J Am Coll Health 26(4): $362 \mathrm{~S}-365 \mathrm{~S}$.

10. Mbata TI, Debiao LU \& Saikia A (2008). Antibacterial activity of the crude extract of Chinese green tea (Camellia sinensis) on Listeria monocytogenes. Afr $J$ Biotechnol 7(10): 1571-1573.

11. Thasleema SA (2013). Green tea as an antioxidant-a short review. J Pharm Sci 5(9): 171-173.

12. Sakanaka S, Kim M, Taniguchi M \& Yamamoto T (1989). Antibacterial substances in Japanese green tea extract against Streptococcus mutans, a cariogenic bacterium. Agric Biol Chem 53: 2307-2311.

13. Ullah H, Ullah A, Raziq A, Lateef M, Khan NM \& Khan MW (2020). Role of phytochemicals in regulation of cancer cells: A comprehensive literature review. Ann Cancer Res Ther 28(2): 143-151.

14. Wang YF, Shao SH, Xu P, Yang XQ \& Qian LS (2011). Catechin-enriched green tea extract as a safe and effective agent for antimicrobial and antiinflammatory treatment. Afr $J$ Pharm Pharmaco 5(12):1452-1461.

15. Farjana A, Zerin N \& Kabir MS (2014). Antimicrobial activity of medicinal plant leaf extracts against pathogenic bacteria. Asian Pac J Trop Dis 4:S920-S923.

16. Bancirova M (2010). Comparison of the antioxidant capacity and the antimicrobial activity of black and green tea. Food Res Int 43(5): 1379-1382. 
17. Khan H, Khan MA \& Abdullah (2015). Antibacterial, antioxidant and cytotoxic studies of total saponin, alkaloid and sterols contents of decoction of Joshanda: Identification of components through thin layer chromatography. Toxicol Ind Health 31(3): 202-208.

18. Khan H, Saeed M, Muhammad N \& Perviz S (2016). Phytochemical analysis, antibacterial, and antifungal assessment of aerial parts of Polygonatum verticillatum. Toxicol Ind Health 32(5): 841-847.

19. Radji M, Agustama RA, Elya B \& Tjampakasari CR (2013). Antimicrobial activity of green tea extract against isolates of methicillin-resistant Staphylococcus aureus and multi-drug resistant Pseudomonas aeruginosa. Asian Pac J Trop Biomed 3(8): 663-667.

20. Mbuthia SK, Wachira FN \& Koech RK (2014). In vitro antimicrobial and synergistic properties of water soluble green and black tea extracts. Afr $J$ Microbiol Res 8(14): 1527-1534.

21. Cho YS, Oh JJ \& Oh KH (2010). Antimicrobial activity and biofilm formation inhibition of green tea polyphenols on human teeth. Biotechnol Bioproc E 15(2): 359-364.

22. Annunziata G, Maisto M, Schisano C, Ciampaglia R, Daliu P, Narciso V, Tenore GC, \& Novellino E (2018).
Colon bioaccessibility and antioxidant activity of white, green and black tea polyphenols extract after in vitro simulated gastrointestinal digestion. Nutrients 10(11): 1711-1718.

23. Henning SM, Yang J, Hsu M, Lee R-P, Grojean EM, Ly A, Tseng C-H, Heber D, \& Li Z (2018). Decaffeinated green and black tea polyphenols decrease weight gain and alter microbiome populations and function in diet-induced obese mice. Eur. J. Nutr 57(8): 2759-2769.

24. Yang X, Kong FJ (2016). Evaluation of the in vitro $\alpha$-glucosidase inhibitory activity of green tea polyphenols and different tea types. J. Sci. Food Agric 96(3): 777-782.

25. Bagheri R, Rashidlamir A, AshtaryLarky D, Wong A, Alipour M \& Motevalli MS (2020). Does Green Tea Extract Enhance the Anti-inflammatory Effects of Exercise on Fat Loss? Br J Clin Pharmaco 86(4): 753-762.

26. Mohanpuria P, Kumar V \& Yadav SK (2010). Tea caffeine: metabolism, functions, and reduction strategies. Food Sci Biotechnol 19(2):275-287.

27. Archana S \& Abraham J (2011). Comparative analysis of antimicrobial activity of leaf extracts from fresh green tea, commercial green tea and black tea on pathogens. JAPS 1(8): 149-154. 